University of Warwick institutional repository: http://go.warwick.ac.uk/wrap This paper is made available online in accordance with publisher policies. Please scroll down to view the document itself. Please refer to the repository record for this item and our policy information available from the repository home page for further information.

To see the final version of this paper please visit the publisher's website. access to the published version may require a subscription.

Author(s): Mark Harrison

Article Title: Soviet industry and the red army under Stalin: a militaryindustrial complex?

Year of publication: 2003

Link to published version:

http://www.cairn.info/article.php?ID_ARTICLE=CMR_442_0323

Publisher statement: None 
SOVIET INDUSTRY AND THE RED ARMY UNDER STALIN:

A MILITARY-INDUSTRIAL COMPLEX?

\author{
Mark Harrison
}

No 609

WARWICK ECONOMIC RESEARCH PAPERS

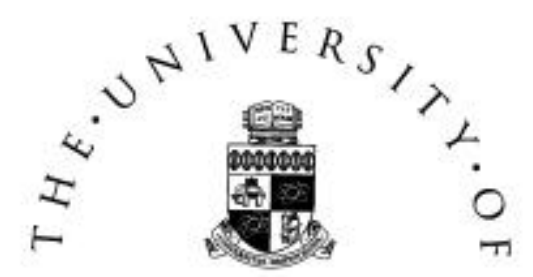

WARWICK

DEPARTMENT OF ECONOMICS 


\title{
Soviet Industry and the Red Army Under Stalin: A Military-Industrial Complex?
}

\author{
Mark Harrison* \\ Department of Economics \\ University of Warwick \\ Coventry CV4 7AL \\ +44247652 3030 (tel.) \\ +442476523032 (fax) \\ Mark.Harrison@warwick.ac.uk
}

\section{Abstract}

The paper considers some of the views of the Stalin-era relationship between Soviet industry and the Red Army that are current in the literature, and disentangles some confusions of translation. The economic weight of the defence sector in the economic system is summarised in various aspects. The lessons of recent archival research are used as a basis for analysing the army-industry relationship under Stalin as a prisoners' dilemma in which, despite the potential gains from mutual cooperation, each party faced a strong incentive to cheat on the other. It is concluded that the idea of a Soviet military-industrial complex is not strictly applicable to the Stalin period, but there may be greater justification for the Soviet Union after Stalin.

\section{Acknowledgements}

* This is a paper to the seminar on "Serving the State: Administrative Practices in the Soviet Union" sponsored by The Centre for Russian, Soviet and Post-Soviet Studies, École des Hautes Études en Sciences Sociales, Paris, with the collaboration of the University of Paris 1-Panthéon-Sorbonne, at the Maison des Sciences de l'Homme, 14-15 December, 2001. Thanks to the Leverhulme Trust, the British Academy, and the University of Warwick for financial support of my research on "Invention, Imitation, and the Birth of Soviet Aerospace", and to Peter Law for advice. 


\section{Soviet Industry and the Red Army Under Stalin: A Military-Industrial Complex?}

\section{Introduction}

In recent years it has been hard to pick up a book or article written in any language about Soviet defence without finding reference to the Soviet military-industrial complex. But the term is typically used in two or three quite different ways.

First, there are those who use the term "military-industrial complex" with and without definition. On one side are most Russians and some westerners to whom its meaning is self-evident and does not require any special definition. ${ }^{1}$ On the other side are those who take the trouble to define what they mean by it. ${ }^{2}$ It appears that the more carefully one defines the military-industrial complex the harder it is to apply to the Soviet Union, to the point where a few writers prefer not to use it at all. ${ }^{3}$

Second is a linguistic differentiation across which those who avoid definitions can slide unnoticed. "Military-industrial complex" is usually translated into Russian as voenno-promyshlennyi kompleks (VPK for short) and conversely. Yet these mean different things. In the English term "military" and "industrial" carry equal weight as adjectival qualifiers of the "complex"; in other words, it refers to a complex made up equally by military and industrial interests. But in the VPK "voenno-" (= military) qualifies "promyshlennyi" (= industrial), not the "complex"; in other words, it refers to a complex made up by the interests of the "military industries", not of the military and industry. ${ }^{4}$ Which is intended? Perhaps we should be told.

A discussion of such issues may perhaps be too late. The "military-industrial complex" has entered everyday language with the result that this term will be used in many contexts with many meanings that social scientists cannot control. For example "military-industrial complex" is now used as an official designation for some Russian defence industry corporations like VPK "MAPO" (Military-Industrial Complex

"Moscow Aviation Production Association", formed in 1996 by a merger of MAPO$M i G$ with other defence producers). Social scientists who wish to speak the language of every day must live with such uses. However, there is merit in seeking periodically to check the drift between everyday language and more specialised uses in the light of new knowledge. An opportunity is presented by new research on the Soviet defence industry and its relationship with the Red Army in the 1930s and 1940s. Hence the purpose of this paper is consider the implications of this research for our understanding of the Soviet army-industry relationship under Stalin.

This paper is organised in six parts. Part 1 reviews past and present-day uses of the concept of a military-industrial complex in relation to the Soviet Union. Part 2 develops a particular aspect of this concept, that of collusion between military and industrial interests in lobbying for resources. Parts 3 and 4 consider evidence concerning Soviet military procurement outcomes and procedures. Part 5 casts this evidence in the framework of a prisoners' dilemma. Part 6 concludes.

${ }^{1}$ For example Scott and Scott (1979), 283-301 (chapter 9, "The Soviet MilitaryIndustrial Complex and Defence Costs"), Aniskov and Khairov (1996); Savitskii (1996); Simonov (1996a) and (1996b); and Samuelson (1996) and (2000). (2000).

${ }^{2}$ For example Holloway (1983); Albrecht (1993); Bystrova (1996), (1997), and

${ }^{3}$ For example Cooper (1991); Barber, Harrison, Simonov, and Starkov (2000); and Harrison (2001a).

${ }^{4}$ For further discussion see Barber, Harrison, Simonov, and Starkov (2000), 2328.

This draft 8 October, 2001. Please do not cite. 


\section{The Concept of a Military-Industrial Complex}

On 17 January 1961 the retiring US President Dwight D. Eisenhower gave a parting warning to the American people. ${ }^{5}$

Until the latest of our world conflicts, the United States had no armaments industry. American makers of plowshares could, with time and as required, make swords as well. But now we can no longer risk emergency improvisation of national defense; we have been compelled to create a permanent armaments industry of vast proportions. Added to this, three and a half million men and women are directly engaged in the defense establishment. We annually spend on military security more than the net income of all United States corporations.

This conjunction of an immense military establishment and a large arms industry is new in the American experience. The total influence - economic, political, even spiritual -is felt in every city, every State house, every office of the Federal government. We recognize the imperative need for this development. Yet we must not fail to comprehend its grave implications. Our toil, resources and livelihood are all involved; so is the very structure of our society.

In the councils of government, we must guard against the acquisition of unwarranted influence, whether sought or unsought, by the military-industrial complex. The potential for the disastrous rise of misplaced power exists and will persist.

The idea was further developed from seeds already sown by C. Wright Mills in an influential work of political sociology published in 1956. Among the significant themes of The Power Elite was that of the new connectedness of America's political, military, and industrial leaders. ${ }^{6}$ From these beginnings the idea of the militaryindustrial complex was developed in various directions, but the common thread was of a coalition, sometimes even a conspiracy, among military and industrial interests and political representatives to lobby for lucrative weapons programmes so as to extract rents from the political process. ${ }^{7}$ The argument was not just about pressure, but about collusion: for the "conjunction of an immense military establishment and a large arms industry" to constitute a military-industrial complex, it was necessary that the pressure brought to bear on politicians by military and industrial interests should be coordinated among them rather than competitive between them. Finally, the argument that American policy was dominated by a powerful military-industrial complex was buttressed by a strongly held belief that David Holloway identified: "that the United States has spent more than is necessary on defence".

A few scholars have investigated the applicability of the concept of the militaryindustrial complex as a broad military and industrial coalition to the Soviet Union. All have found it difficult to specify, let alone identify empirically, the character of collusion that would have to be found to enable us to confirm that there was indeed a Soviet military-industrial complex in this sense.

Mikhail Agursky and Hannes Adomeit came to the most sweeping conclusion. ${ }^{9}$ They claimed to have found:

a core of truth in the aphorism that "the USA has a military-industrial complex, the USSR is a military-industrial complex".

\footnotetext{
${ }^{5}$ Eisenhower (1961), 1035-1040

${ }^{6}$ Mills (1956), especially 171-224 (chapters 8, “The Warlords", and 9, “The Military Ascendancy").

${ }^{7}$ Rosen (1973), 3.

${ }^{8}$ Holloway (1982), 293.

${ }^{9}$ Agursky and Adomeit (1978), 6.
} 
They drew this from a comparison of the United States political structure, open to pressure from a range of interests in society, civilian as well as defence-related, with the closed political structure of the Soviet state from which independent civilian interests capable of resisting military-industrial pressures were excluded. They hesitated to carry the implication to extremes, however, concluding that:

to consider the whole of the Soviet Union as a military-industrial complex is far too broad to be meaningful.

Vernon Aspaturian presented two alternative hypotheses or 'prototypes' of the Soviet military-industrial complex, one weaker and the other stronger. ${ }^{10}$ The stronger sense, he argued, was of:

an interlocking and interdependent structure of interests among military, industrial, and political figures, that enables or impels them to behave as a distinctive political actor separate from its individual components. A complex of this type [...] would exhibit a high degree of policy unity and act as a single input into the political system.

For the Soviet Union to conform to the stronger hypothesis it would be necessary to identify the influence of the military-industrial complex exerted by its representatives acting in unison. In the weaker hypothesis, its influence would be seen in military, industrial, and political leaders acting separately, but in harmony, to promote shared objectives, in other words through:

a deliberate and symbiotic sharing of interests on the part of the military establishment, industry, and high-ranking political figures, whose collective influence is sufficient to shape decisions to accord with the interests of these groups at the expense of others in Soviet society.

Aspaturian's own preference was for something in between harmony and unison, "much more than the first prototype and something less than the second".

Peter Almquist concurred with Aspaturian's weaker hypothesis and argued that a model of collusion based on harmony was more realistic that one based on unison. $\mathrm{He}$ agreed that shared interest must underlie the idea of a military-industrial complex: ${ }^{11}$

For a military-industrial complex to exist in a meaningful way, the military and its supporting industries must have, first, complementary interests. By this it is meant that one of the 'partners' generally benefits from the self-interested actions of the other [...]

As distinct from shared interest, however, Almquist suggested that shared purpose must be capable of independent and separate expression:

Second, and equally important, both the military and the industry must have a means of influencing the political decision makers. In a military-industrial complex, a "silent partner" is an irrelevant partner [...]

Most recently Irina Bystrova, specifically dissociating herself from those who identified the military-industrial complex narrowly with the defence industry and its leaders, has argued for a return to a wider and also stronger conception of the Soviet military-industrial complex as: ${ }^{12}$

a powerful corporation that represented the common interests of social-political groups associated with the provision of the USSR's national security: professional soldiers, party and state officials, representatives of the security agencies, and scientific-technical circles. In our view, the term "power elite" applies even more closely to the Soviet VPK than to the American, where the element of [private] property relations and economic dominance somewhat obscured a "pure" portrayal of political power.

\footnotetext{
${ }^{10}$ Aspaturian (1973), 103.

${ }^{11}$ Almquist (1990), 12-13.

${ }^{12}$ Bystrova (1997), 35, and (2000), 9 (emphasis added)..
} 
As will become clear, however, Bystrova limits the empirical application of this concept to the post-Stalin period.

\section{Collusive Lobbying: a Rationale}

Under what circumstances may either the army or industry have something to gain from investments in lobbying?

Under any constitution, various aspects of military budgeting and procurement make these a suitable target for lobbying activity. The funding principal takes decisions in secret and often does not have to account for them even afterwards in a transparent way. Much military spending has an insurance aspect, but the worst cases against which the principal seeks to insure are not susceptible to actuarial calculation. Where military projects involving new technologies are concerned there is usually intrinsic uncertainty about the timescale and expected value of returns to investment. It may be rationally expected that many projects will fail. There are powerful information biases: agents know the true worth of their projects better than the principal does. All of these impede the principal in the course of both selection and monitoring of spending programmes. Under these circumstances self-interested agents from within both military and industrial organisations can be expected to invest resources in lobbying the principal for funding of their own projects.

This on its own does not mean that more will be spent on defence in the presence of lobbying than without it; it just means that the military budget will be allocated in a way that reflects the effectiveness of lobbying investments. If the resources invested are taken out of the sums nominally allocated to national defence, then it could even mean that true defence spending is less than appears. For such lobbying to increase the total of resources available for national defence in a market economy it appears to be also necessary that the budget constraints on military projects should be relatively soft. Alternatively, in a command system like the Soviet economy where all budget constraints were soft to some degree, it would be necessary for the military budget also to have some degree of priority in the rationing of material supplies, which was in fact the case. Under these circumstances military and defence-industry interests will be able to invest more in lobbying than their civilian counterparts and will anticipate a higher return on lobbying investments. As a result, military procurement will claim more resources than an uncorrupted principal would have allocated.

When rivalrous lobbying can influence the principal, why should agents collude? The reason is that unrestricted rivalry dissipates the rents they extract. In the simplest case, if $n$ risk-neutral agents are competing for a given sum of project funding that offers a net surplus $k$ and each has the same expectation of being awarded the contract, then each should be willing to invest $\frac{k}{n}$ in lobbying to win the contract and the result will be that the entire surplus available is competed away in lobbying costs. However, if two agents secretly collude they can pool their probabilities of winning the contract, reduce their joint costs of lobbying, and so gain.

When collusion pays, why should military and industrial agents collude among themselves rather than with others? For example, the Red Army annually procured very large quantities of food. Farmers and soldiers both stood to gain from increased investments in food production and procurement for the armed forces. Therefore, why not a "military-agricultural complex" in which farmers and soldiers colluded to lobby for increased agricultural investment? One reason might be that soldiers and weapon producers could hide collusion more easily under a common cloak of secrecy than any other coalition one could think of. For another reason, it is commonly held that the success of collusion depends in part on the frequency and repetitiveness of interaction between agents that may collude. From this point of view the interaction between soldiers and industrialists was far more intense and far more likely to give 
rise to long-term relationships. If the Red Army and Soviet industry could not learn to trust each other, no one could.

Finally, consider the motivation of the funding principal who is the target of lobbying. Why should a principal permit any lobbying? One reason may be that lobbying provides the principal with more information than in its absence, even if the information itself may contain biases. This information is of two kinds: about the relative worth of the spending projects from among which he must choose, and about the relative loyalty of the agents competing for his favour.

A dictator, for example, might intentionally design the budgetary system to distribute rewards to loyal agents. As a result public spending will be larger than on a pure public-good calculation of the costs and benefits. The excess is the signal that loyalty is being rewarded and expected in return; if some extra spending did not result, those receiving the funding would have no reason to offer thanks to the government in exchange since any politician would rationally promise to undertake at least those expenditures that were efficient. ${ }^{13}$ A dictator like Stalin, already closely linked with military and industrial interests, might rationally choose military spending for one of the channels through which he distributed rewards, and military spending would then also be enlarged.

However, such a dictator should prefer his agents to compete, not collude, in lobbying him. This is for two reasons: first, collusion among agents would restrict the flow of information and probably increase its inherent biases. Second, collusion would enable them to increase both the level of rents extracted, and the proportion extracted not as a reward for loyalty but as a return on lobbying investments. The implication is that, if military and industrial interests succeeded in colluding in such a way as to form a military-industrial complex, then the dictator was failing to rule efficiently in some degree.

\section{Evidence on the Defence Burden}

How can we tell whether there was a Soviet military-industrial complex? I have outlined an argument that collusive lobbying by military and industrial interests should lead to more spending than is necessary on defence. Some have been tempted, therefore, to seek to resolve this question by looking at outcomes. If a particular society shows a particularly high level of military spending, perhaps that is evidence that a military-industrial complex is at work. By this criterion, however, the case of the Soviet Union under Stalin would not be especially clear cut.

It is true that the Soviet Union, although a relatively poor country, allocated somewhat greater resources to defence than other countries at a similar level of development for much of the twentieth century. For most of the interwar period, for example, most other European countries, including the United Kingdom, were spending 2 to 3 per cent of their national incomes on defence, and the United States even less. ${ }^{14}$ In contrast the peacetime share of Soviet military spending rose unremittingly from 2 per cent in 1928 to 6 per cent in 1937 and 15 per cent in $1940 .{ }^{15}$

\footnotetext{
${ }^{13}$ Wintrobe (1998), 31.
}

${ }^{14}$ Eloranta (2000), 27, has collected figures for the interwar defence burden on nine smaller European countries, from which the unweighted means may be computed at 2.3 per cent in 1925 and 2.6 per cent in 1935. The same figures for the United Kingdom were 2.6 and 3.0 per cent of GNP, computed from Feinstein (1972), 1 and 33, and for the United States only 1.2 per cent as late as 1938, from Rockoff (1998), 83.

\footnotetext{
${ }^{15}$ Bergson (1961), 46.
} 
Even so, the 1937 Soviet figure is only slightly in excess of the 5 per cent recorded for the Russian Empire in 1913. ${ }^{16}$ Moreover, the argument that the Soviet Union was spending more than was necessary on defence is undermined by two stubborn facts. One is that a war was coming. In 1937 Germany was already spending 15 per cent of national income on military rearmament. ${ }^{17}$ Given the relative sizes of the two economies, Soviet real military outlays at this time were probably only half Germany's. ${ }^{18}$ The other is that the peacetime burdens were modest by comparison with those imposed by war itself. War drove the defence share far higher: as a share of GDP at prewar prices the Soviet military burden rose from 17 percent in 1940 to more than 60 per cent in 1942 and 1943 before falling back to 9 per cent by $1950 .{ }^{19}$

It is true that after the Korean rearmament the Soviet economy again carried a burden consistently higher than that of its main rival. The Soviet postwar military burden was lower, and shows less variation both across estimates and through time, than is often supposed, but still exceeded figures reported for the United States. Higher estimates of Soviet defence share of GDP vary within a 13 to 16 per cent range from the 1960s through the 1980s, while lower estimates give a range of 10 to 13 percent. ${ }^{20}$ United States figures are lower: they show 9 per cent in 1960 falling to 8 per cent in 1970 and less than 6 per cent in $1980 .{ }^{21}$ But again it is necessary to take into account that the US economy was never less than twice the size of the Soviet economy in the postwar period.

It has been argued that such ratios understate the scope of the Soviet militaryeconomic effort in comparison with other countries. At the end of the 1970s, for example, Harriet and William Scott wrote: ${ }^{22}$
A number of Soviet dissidents argue that over 40 percent of the Soviet gross national product goes for military purposes. Their rationale may take into account hidden costs for which there are no counterparts in the United States. [...] To [the regular Soviet military program] must be added paramilitary training of the population and premilitary and reserve training. Civil defense programs, hardening of both military and industrial facilities, and dispersion and duplication of industries for defense purposes are additional costs. The costs of highways and railroads constructed primarily for strategic purposes, even though they have some peacetime use, must be considered. Foreign military aid is another factor.

More recent writing in this vein has focused on the special role of mobpodgotovka (mobilisation readiness) in the Soviet economy. ${ }^{23}$ For example, in his foreword to Lennart Samuelson's recent book on Tukhachevskii, Vitalii Shlykov describes how: ${ }^{24}$

${ }^{16}$ Gregory (1982), 57.

17 Abelshauser (1998), 138.

${ }^{18}$ For size comparisons of GDP here and below see Maddison (2001).

${ }^{19}$ For the war years see Harrison (1996), 110, and for 1950 Bergson (1961), 46.

${ }^{20}$ Easterly and Fischer (1995), 348.

${ }^{21}$ Smith and Smith (1983), 23.

${ }^{22}$ Scott and Scott (1979), 283.

${ }^{23}$ For accounts of mobpodgotovka in the 1930s see Simonov (1996), 115-25, and Simonov (2000).

${ }^{24}$ Samuelson (2000), xii (emphasis added). Shlykov goes on: "[...] until the publication of this book and Samuelson's other writings these preparations were inadequately evaluated and understood both by Western Sovietologists and by the wartime adversaries of the Soviet Union, especially Germany". 
the Soviet economy very rapidly became an economy of total preparation for war. To enable the transition from civilian to military production an elaborate and strictly centralised system of mobilisation readiness was established at every level of Soviet power and in all the agencies of economic administration down to the factory level.

In my view too much should not be made of these arguments, certainly where the Stalin period is concerned. For one thing the Soviet authorities certainly intended to create an all-embracing system of mobilisation preparation, but whether they succeeded in doing so, or merely in creating the appearance of it, has not yet been sufficiently researched. For another, while mobpodgotovka was aimed at enhancing the Soviet Union's military potential, the nature of an economic potential is that in the outcome it may yet be used for other purposes. Many Soviet outlays that were defence-related without being counted in the military budget either contributed more to goals other than to defence (for example, the maintenance of large internal security forces the primary task of which was defence of the regime against its internal enemies), or else added to the economy's general potential through the accumulation of fixed assets and the stock of knowledge. In the Soviet Union as in other countries, finding a strategic rationale for something desired for other reasons was always an effective way of pushing it up the budgetary agenda. Finally, there are parallels in other countries from the origins of Germany's autobahn network in the consolidation of Hitler's regime of the 1930s to the Defense \& Interstate Highways built in the United States after World War II.

The main problem with using high levels of military spending to detect the presence of a military industrial complex, however, is that high Soviet military spending may be explained otherwise than by the collusive lobbying of military and industrial interests. It might be that competitive lobbying was powerful enough to secure additional outlays. It might be that the Soviet dictator designed the budgetary process intentionally to reward loyal agents in the military and industrial sectors. Finally, it might be that high military spending was justified on public-good grounds of Soviet national security simply as a response to external threat perceptions.

Related to the national security argument is the possibility that the Soviet Union spent more on defence simply because it was a dictatorship. Michelle Garfinkel has argued that incumbent policy-makers in competitive political systems have an incentive to underinvest in national security in the face of a given threat, because the likelihood of being replaced in the short-term by another policy-maker with different goals prevents the incumbent from fully internalising the long-term benefits. ${ }^{25}$ Given that threats are not actually given but are determined by interaction between states, the outcome can be a good equilibrium of low military spending in regions where democracies predominate. Garfinkel also shows empirically that democratic states have tended to spend less on defence than non-democratic ones. As a possible explanation of high levels of Soviet military spending this has nothing to do with lobbying or special interest groups.

In summary, if we wish to detect the operation of a military-industrial complex we cannot rely on statistical indicators of the outcomes of military budgeting and procurement. We have to find direct evidence of the process that gave rise to the outcome. This evidence should substantiate the hypothesis of a coalition among military and industrial interests in lobbying for resources.

\section{Evidence on Collusion}

Irina Bystrova has suggested a useful distinction between lower-level lobbying by agents within ministerial departments, which I will call lobbying for project funding,

\footnotetext{
${ }^{25}$ Garfinkel (1994).
} 
and the sort of higher-level lobbying that ministers and ministries engaged in where the funding of entire ministerial programmes was at stake. ${ }^{26}$

Recent archive-based studies have thrown light on lobbying for project funding in defence industry. "The activity of creating monopolies is a competitive industry", and the Soviet aircraft industry was no exception. ${ }^{27}$ Mikhail Mukhin's study of aircraft designers suggests that rivalry, far from being artificially engendered from above, was intrinsic, intense, and amoral. ${ }^{28}$ Harrison's accounts of aeroengine innovation show that rivalry began with each inventor's struggle to gain a firstmover's advantage over competitors for influence over the funding principal. Their competition was developed through behaviours that aimed to establish and defend a monopoly over intellectual and physical assets of various kinds. An active market for second-hand assets was expressed through activities such as hostile takeover bids and mergers. ${ }^{29}$ While each struggled to create a personal monopoly, there is little evidence of collusive behaviour among agents. Bystrova considers it typical, for example, that one designer would refuse to take on the former employee of another. ${ }^{30}$

Evidence of intense competition for project funding does not settle the issue of whether or not there was collusion among military and industrial interests at higher levels in the political system in lobbying for ministerial programmes. For example, if military and industrial interests successfully colluded to extract some of the dictator's rent, they might reasonably also agree to use competitive lobbying at lower levels to distribute the surplus among the agents within the military-industrial complex.

In this connection a story told by Irina Bystrova is suggestive. In the spring of 1946 following the "aviators' affair" the new air force chief K.A. Vershinin reported to Stalin that one reason for the technical backwardness of Soviet aviation was that aircraft designers had too much control over the air force's plan for experimentation, and that they had achieved this control because design work had become too monopolised, with only three bureaux for fighter aircraft and one each for other types. ${ }^{31}$ The significance of this case lies in several implications: the designers' competitive struggle to create a monopoly had in part succeeded, perhaps as a result of wartime conditions; previous leaders of the air force and aircraft industry had colluded, but for the sake of a quiet life rather than to distribute rents; such collusion had damaged the interests of the armed forces as a whole; and the new air force chief lobbied the dictator to correct this. Finally, it is significant that the dictator agreed.

Is there direct evidence of collusion between ministries that is more than anecdotal? Consider first the lower levels of daily interaction between the industrial producers and the military consumer of defence products. Here the evidence is almost entirely of tension. ${ }^{32}$ Producers tried to inflate prices and persuade the consumer to accept and pay for products than fell below contractual standards. Defence ministry regulators in industrial establishments struggled to secure information about costs and verify claims about deliveries and quality standards. Collusion took the form of military regulators accepting bribes from producers to make decisions in favour of

${ }^{26}$ Bystrova (2000), 317.

${ }^{27}$ For the aphorism see Tullock (1987), 604.

${ }^{28}$ Mukhin (2000).

${ }^{29}$ Harrison (2001b) and (2001c).

${ }^{30}$ Bystrova (2000), 319.

${ }^{31}$ Bystrova (2000), 320-1.

${ }^{32}$ For an account of the military procurement system in the 1930s see Harrison and Simonov (2000). 
industry rather than the armed forces. The consistent policy of the defence ministry was to legislate against collusion and punish it when it was detected.

If we raise our sights to higher levels of the political system, is there evidence that the commissars for defence and the defence industries, say, colluded to win enhanced funding for ministerial programmes? The archives confirm that the army and heavy industry each separately pressed for additional resources at various times. ${ }^{33}$ But did they pursue their interests jointly? Evidence of collusion - for example, that military leaders were prompted or induced to press for increased allocations by industrialists, or conversely - has not been found. In general the daily interaction of industrial and defence officials suggests that mutual tensions, frustrations, suspicions, and conflicts between the army and industry were endemic. ${ }^{34}$

Bystrova has shown that at key moments the voice of the armed forces was conspicuously absent. For example, when minister for the chemical industry M.G. Pervukhin fought for more resources for the uranium industry after World War II, it was within a framework that excluded the military: the Special Committee appointed by Stalin to take charge of atomic weapons development had no armed forces representatives. ${ }^{35}$ When minister for armament D.F. Ustinov struggled against Moscow's civilian administration for more factory space for jet and rocket armament in the same period Stalin settled the dispute, not pressure from the armed forces. ${ }^{36}$

It appears that industry and army had little opportunity to act in concert, and even the influence that each could exert separately was strictly constrained by the political system in which they operated. While the interests of Soviet society were explicitly identified with both military and industrial construction, the concentration of power $n$ the central party organs and the ubiquitous role of the party-state apparatus meant that military and defense-industry interests had little or no freedom of independent action. Civilian leaders from Stalin onwards retained complete authority through prewar rearmament, World War II, and postwar military confrontations. The political influence of outstanding soldiers was always tenuous, from chief of Red Army armament Marshal M.N. Tukhachevskii, executed by Stalin in 1937, to air force Marshal A.A. Novikov, imprisoned by Stalin in 1946, and Marshal G.K. Zhukov, sacked first by Stalin in 1946, then by Khrushchev in 1957.

If any branch of government developed an organic relationship with the defense industry at this time, it was the security organs under the leadership of the civilian minister for internal affairs and deputy prime minister L.P. Beriia. The latter, like Stalin's postwar commander of ground forces N.A. Bulganin, held the military rank of Marshal, but neither was a professional military man. Boris Starkov has shown from the archives that Beriia shared Stalin's distrust of the professional soldiers to the point where, in the early 1950s, he even opposed handing over his newly developed nuclear weapons to the armed forces. ${ }^{37}$

What explains the absence of collusion? The structure of individual incentives was evidently such that the private gains to collusion were typically less than the gains from acting in rivalry. In other words the absence of collusion may be explained in terms of a prisoners' dilemma. ${ }^{38}$

${ }^{33}$ For various examples see Samuelson (1996) and (2000); Davies and Harrison (1997).

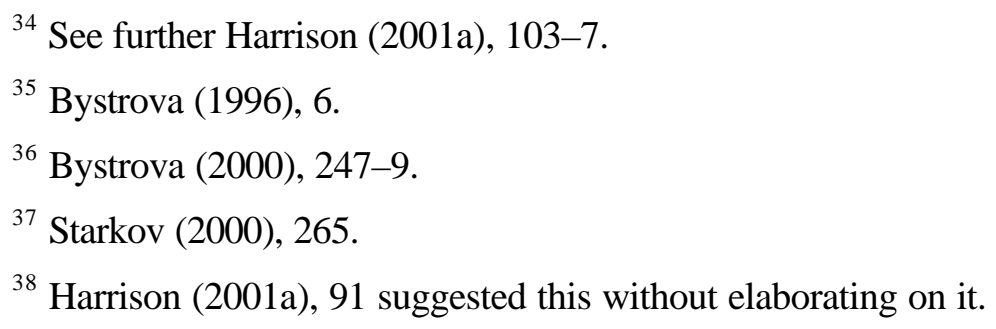




\section{A Prisoners' Dilemma}

The concept of the prisoners' dilemma describes a class of games in which the players would gain jointly if they could only cooperate with each other. However, to prefer cooperation they need some means of making a binding commitment beforehand to cooperate and share the mutual gain. Without this mutual trust each is better off cheating on the other. ${ }^{39}$

The dilemma in the Soviet military-industrial complex could be described as follows. Consider two players, Army and Industry, under a Dictator who fixed the demands upon each and allocated the resources with which each must meet these demands. Think of each player as aiming to maximise their own resources relative to the demands placed on them by the Dictator. In other words each player sought to minimise plan tension - the degree of effort or "mobilisation" they must exert to achieve the demands placed on them, but since they could not easily control these demands the best way of achieving this goal was to lobby for additional resources.

A problem for each was that the additional resources must come from somewhere. When the Army, for example, faced the Dictator with a demand for more resources, the Dictator had to decide where to find them, and this must have detracted either from the Dictator's objectives for living standards, or for investment in agriculture or trade, or it must have resulted in harder work and lower pay for Industry. When Industry pressed the Dictator for more resources, the Dictator could similarly choose to find them from agriculture or consumption, or by making the Army wait longer for new weapons. By colluding and lobbying jointly, Army and Industry could make it harder for the Dictator to make the other pay and easier for him to decide to sacrifice consumption and agriculture instead. Thus each might support the other's case for more resources.

Suppose Army and Industry acted on this logic. Before the game each might promise the other to adopt a high plan rather than a low plan. Industry would propose a high plan for the output of military products (plan voennoi produktsii), and the Army would propose a high plan for the matching procurement of military products (plan voennykh zakazov). But in playing the game each could choose either to honour its commitment to go high, or cheat on the other by going low.

A possible set of payoffs to each player and each strategy is set out in figure 1 . When both went low, each neither gained nor lost but simply received the allocation that the Dictator decided without influence being exerted. When both went high, each gained. This gain was at the expense of the Dictator, or to be precise at the expense of the Dictator's other objectives, say, to develop the civilian sector.

In the other cases one went high and the other low. This shifted the balance of power in the market for military products: whoever cheated was able to shift this balance against the other. When the Army went high and Industry low, it appeared as if the Dictator had favoured the Army by augmenting its budget for weapons and

${ }^{39}$ See for example Gibbon (1992), 3: "Two suspects are arrested and charged with a crime. The police lack sufficient evidence to convict the suspects, unless at least one confesses. The police hold the suspects in separate cells and explain the consequences that will follow from the actions they could take. If neither confesses then both will be convicted of a minor offense and sentenced to one month in jail. If both confess then both will be sentenced to jail for six months. Finally, if one confesses but the other does not, then the confessor will be released immediately but the other will be sentenced to nine months in jail - six for the crime and a further three for obstructing justice". Although the total time served by the two would be minimised at two months (one month each) if each remained silent, each player is individually better off confessing regardless of the other's action. If B remains silent, A gets off free by confessing rather than serve a month in jail. If B confesses, A serves six months by confessing too, rather than serving nine by remaining silent. 
military equipment. But the reality was that the Army faced a seller's market in which the supply of munitions was restricted; the Army found its favourable budget eroded by inflation as producers pushed up prices faster than expected, and the Army could only succeed in procuring weapons in the numbers envisaged by relaxing quality standards. Thus Industry could gain at the Army's expense.

Figure 1. Industry versus Army

\begin{tabular}{|c|c|c|c|}
\hline & \multicolumn{2}{|c|}{ Army } \\
\hline & & High & Low \\
\hline & High & $\begin{array}{l}\text { Army and Industry both gain } \\
\text { at the expense of the Dictator } \\
\qquad(1,1)\end{array}$ & $\begin{array}{l}\text { Buyer's market: Army gains } \\
\text { at expense of both Dictator } \\
\text { and Industry by imposing } \\
\text { lower prices and higher } \\
\text { quality standards } \\
\qquad(-1,2)\end{array}$ \\
\hline ndustry & & $(2,-1)$ & $(0,0)$ \\
\hline & Low & $\begin{array}{r}\text { Seller's market: Industry } \\
\text { gains at expense of both } \\
\text { Dictator and Army by } \\
\text { imposing higher prices and } \\
\text { lower quality standards }\end{array}$ & $\begin{array}{l}\text { Neither Army nor Industry } \\
\text { gains or loses. }\end{array}$ \\
\hline
\end{tabular}

In the other case Industry went high and the Army low, so it appeared as if the Dictator had favoured Industry by permitting rapid expansion of its production and capacity. But in reality Industry now faced a buyer's market in which the Army could exploit the increased availability of munitions; the Army could pick and choose among producers and products, exert downward pressure on prices, and control quality more effectively by making it more difficult for Industry to realise its plan for deliveries. Thus the Army could gain at Industry's expense.

In short, the joint gain of both players was greatest when both went high: in figure 1, each gained 1. But Industry gained by cheating whether or not the Army cheated. If the Army went high Industry received 1 if it went high too, but 2 if it cheated and went low. If the Army cheated and went low, Industry received zero if it cheated too, but -1 if it went high. Either way Industry would prefer to cheat. A glance at the figure shows that the position of the Army was symmetrical.

Finally, the textbook analysis of the prisoners' dilemma tells us that the tendency to cheat could be overcome in specific circumstances: if each player could learn to trust the other as a result of repeated interactions. Aware of this, Stalin demanded that his agents be loyal to him, not to each other, and took measures to speed up the circulation of nomenklatura posts to prevent the formation of personal ties. Bystrova refers to this quite correctly as Stalin's policy of "divide and rule". ${ }^{40}$ But in the postStalin era elite circulation slowed down. For example, research on the postwar membership of the Sovnarkom and Council of Ministers has shown that the leaders of the defence and heavy industries made up the core of continuity from the Stalin era to the post-Stalin succession. ${ }^{41}$ Reduced turnover and increased opportunities for

\footnotetext{
${ }^{40}$ Bystrova (2000), 317.

${ }^{41}$ Crowfoot and Harrison (1990), 52.
} 
military and industrial agents to build personal reputations and form personal ties of trust might well have increased the incentives for them to collude with each other.

This provides some theoretical justification for Bystrova's view that the Soviet military-industrial complex only came into its own after Stalin's death, including for her identification of Ustinov personally as the key figure in the post-Stalin militaryindustrial coalition. ${ }^{42}$ His ministerial responsibilities over more than 40 years ranged from the armament industry and the defence industry as a whole to defence itself. ${ }^{43}$

If Ustinov may be remembered as the father of the Soviet military-industrial complex, a more distant ancestor should not be forgotten. Lennart Samuelson's research has revealed that throughout his military career Tukhachevskii advocated high plans for defence industry. In the spring of 1927 as chief of the Red Army general staff he sponsored a project for a military-industrial complex organised not through collusion but by a military takeover of defence industry. His ambition rested partly on a proposal to create a "defence sector" for industrial mobilisation within the state economic planning commission, in which he proposed personally to play the leading role. The Gosplan defence sector was established, but Tukhachevskii was sidelined. ${ }^{44}$ At the same time the defence commissariat requested the right to agree appointments to the defence industry, plans and reports of defence producers, and plans for capital investment in the industry. This proposal was rejected. ${ }^{45}$

Tukhachevskii was resisted in particular by Stalin's defence commissar and loyal agent K.E. Voroshilov. Samuelson has shown that Tukhachevskii's resignation as chief of staff, which followed in May 1928, was most likely a result of the failure of his ambition to control the defence industry. ${ }^{46}$

\section{Conclusion}

To judge from the present-day discourse of Russian history, the Soviet militaryindustrial complex is an established fact. Speaking more strictly, however, this paper suggests that in the Stalin period the military-industrial complex was not yet fully developed. Despite the development of large and diversified armed forces served by large-scale specialised industrial facilities apparently integrated and coordinated through the party-state apparatus, the incentives for the agents of these interests to compete rather than collude were very strong. The dictator personally disliked it when his agents colluded with each other rather than with him, and took steps to break up and punish collusion when it was identified. Only after Stalin's death were conditions created that may have been more favourable to the emergence of a durable military-industrial coalition.

\section{References}

Abelshauser, Werner (1998), "Germany: Guns, Butter, and Economic Miracles", in Mark Harrison, ed., The Economics of World War II: Six Great Powers in International Comparison, Cambridge: Cambridge University Press, 122-76

Agursky, Mikhail, and Hannes Adomeit (1978), "The Soviet Military-Industrial Complex and Its Internal Mechanism”, National Security Series no. 1/78, Queen's University, Centre for International Relations, Kingston, Ontario

\footnotetext{
${ }^{42}$ Bystrova (2000), 328.

${ }^{43}$ Ivkin (1999), 564.

${ }^{44}$ Samuelson (2000), 42-7.

${ }^{45}$ Harrison and Simonov (2000), 230.

${ }^{46}$ Samuelson (2000), 55-9.
} 
Albrecht, Ulrich (1993), The Soviet Armaments Industry, Chur, Switzerland: Harwood Academic Publishers

Almquist, Peter (1990), Red Forge: Soviet Military Industry Since 1965, New York: Columbia University Press

Aniskov, V.T., and Khairov, A.R. (1996), Istoriia voenno-promyshlennogo kompleksa Rossii v regional'nom aspekte: ot nachala pervoi do okonchaniia vtoroi mirovoi voiny. Na primere Verkhnevolzh'ia, Iaroslavl': Iaroslavskii gosudarstvennyi universitet

Aspaturian, Vernon V. (1973), "The Soviet Military-Industrial Complex: Does It Exist?", in Steven Rosen, ed., Testing the Theory of the Military-Industrial Complex, Lexington, MA: Lexington Books, 103-33

Barber, John, Mark Harrison, N.S. Simonov, and B.S. Starkov (2000), "The Structure and Development of the Defence-Industry Complex", in John Barber and Mark Harrison, eds, The Soviet Defence-Industry Complex from Stalin to Khrushchev, London and Basingstoke: Macmillan, 3-29

Bergson, Abram (1961), The Real National Income of Soviet Russia Since 1928, Cambridge, MA: Harvard University Press

Bystrova, Irina (1996), "The Formation of the Soviet Military-Industrial Complex", Stanford University, Centre for International Security and Arms Control

Bystrova, Irina (1997), "Sovetskii VPK. Teoriia, istoriia, real'nost"”, Svobodnaia mysl', no. 6, 30-44

Bystrova, Irina (2000), Voenno-promyshlennyk kompleks SSSR v gody kholodnoi voiny. (Vtoraia polovina 40-kh - nachalo 60-kh godov), Institut Rossiiskoi istorii Rossiiskoi Akademii nauk, Moscow

Cooper, J.M. (1991), The Soviet Defence Industry: Conversion and Reform, London: Pinter

Crowfoot, John, and Mark Harrison (1990), "The USSR Council of Ministers under Late Stalinism, 1945-1954: its Production Branch Composition and the Requirements of National Economy and Policy", Soviet Studies, 42(1), 41-60

Davies, R.W., and Mark Harrison (1997), "The Soviet Military-Economic Effort Under the Second Five-Year Plan (1933-1937)”, Europe-Asia Studies, 49(3), 369-406

Easterly, William, and Stanley Fischer (1995), "The Soviet Economic Decline", World Bank Economic Review, 9(3), 341-71

Eisenhower, Dwight D. (1961), Public papers of the Presidents of the United States, Dwight D. Eisenhower, vol. 8, Washington, DC: US GPO.

Eloranta, Jari (2000), “'Weak' European States in the International Arms Transfer System of the Interwar Period: Responding to External Threats, Domestic Constraints, or Market Influences?", European University Institute, San Domenico di Fiesole, Italy

Feinstein, C.H. (1972), Statistical Tables of National Income, Expenditure and Output of the U.K., 1855-1965, Cambridge: Cambridge University Press

Garfinkel (1994), "Domestic Politics and International Conflict", American Economic Review, 84(5), 1294-1309

Gibbons, Robert (1992), A Primer in Game Theory, Harlow, England: Prentice Hall

Gregory, Paul R. (1982), Russian National Income, 1885-1913, Cambridge: Cambridge University Press

Harrison, Mark (1996), Accounting for War: Soviet Production, Employment, and the Defence Burden, 1940-1945, Cambridge: Cambridge University Press

Harrison, Mark (2001a), "Providing for Defense", in Paul R. Gregory, ed, Behind the Façade of Stalin's Command Economy, Stanford, CA: Hoover Institution, 81110

Harrison, Mark (2001b), "The Soviet Market for Inventions: The Case of Jet Propulsion, 1932 to 1944", The Warwick Economics Research Paper Series no. 605, University of Warwick, Department of Economics 
Harrison, Mark (2001c), "The Political Economy of a Soviet Military R\&D Failure: Steam Power for Aviation, 1933 to 1939”, University of Warwick, Department of Economics

Harrison, Mark, and N.S. Simonov (2000), "Voenpriemka: prices, costs, and quality assurance in defence industry", in John Barber and Mark Harrison, eds, The Soviet Defence-Industry Complex from Stalin to Khrushchev, London and Basingstoke: Macmillan, 223-45

Holloway, David (1982), 'Innovation in the Defence Sector', in Ronald Amann and Julian Cooper, eds, Industrial Innovation in the Soviet Union, New Haven, CT: Yale University Press, 276-367

Holloway, David (1983), The Soviet Union and the Arms Race, New Haven, CT: Yale University Press

Ivkin, V.I. (1999), Gosudarstvennaia vlast' SSSR. Vysshie organy vlasti i upravleniia i ikh rukovoditeli. 1923-1991 gg. Istoriko-biograficheskii spravochnik. Moscow: ROSSPEN

Maddison, Angus (2001), The World Economy: a Millenial Perspective, Paris: OECD

Mills, C. Wright (1956), The Power Elite, New York: Oxford University Press

Mukhin, M.Iu. (2000), "Sovetskoe rukovodstvo 1920-30-kh godov i aviastroitel'nye inzhenerno-tekhnicheskie kadry: ot liubvi do nenavisti — odin shag", Institut Rossiiskoi istorii Rossiiskoi Akademii nauk, Moscow

Rockoff, Hugh (1998), "The United States: From Ploughshares to Swords", in Mark Harrison, ed., The Economics of World War II: Six Great Powers in International Comparison, Cambridge: Cambridge University Press, 81-121

Rosen, Steven (1973), "Testing the Theory of the Military-Industrial Complex", in Steven Rosen, ed., Testing the Theory of the Military-Industrial Complex, Lexington, MA: Lexington Books, 1-29

Samuelson, Lennart (1996), Soviet Defence Industry Planning: Tukhachevskii and Military-Industrial Mobilisation, Stockholm: Stockholm School of Economics

Samuelson, Lennart (2000), Plans for Stalin's War Machine: Tukhachevskii and Military-Economic Planning, 1925-41, London and Basingstoke: Macmillan

Savitskii, I.M. (1996), Oboronnaia promyshlennost' Novosibirskii oblasti. Opyt poslevoennogo razvitiia (1946-1963 gg.), Novosibirsk: "Olsib"

Scott, Harriet Fast, and William F. Scott (1979), The Armed Forces of the USSR, Boulder, CO: Westview

Shcherba, A.N. (1999), Voennaia promyshlennost' Leningrada v 20-30-e gody, St Petersburg: "Nestor"

Simonov, N.S. (1996a), "Voenno-promyshlennyi kompleks SSSR v 20-50-e gody", Svobodnaia mysl', no. 2, , 96-114

Simonov, N.S. (1996b), Voenno-promyshlennyi kompleks SSSR v 1920-1950-e gody: tempy ekonomicheskogo rosta, struktura, organizatsiia proizvodstva $i$ upravlenie, Moscow: ROSSPEN

Simonov, N.S. (2000), "Mobpodgotovka: Mobilisation Planning in Interwar Industry", in John Barber, and Mark Harrison, eds, The Soviet Defence-Industry Complex from Stalin to Khrushchev, London and Basingstoke: Macmillan, 20522

Smith, Dan, and Ron Smith (1983), The Economics of Militarism, London: Pluto

Starkov, B.S. (2000), "The Security Organs and the Defence-Industry Complex", in John Barber and Mark Harrison, eds, The Soviet Defence-Industry Complex from Stalin to Khrushchev, London and Basingstoke: Macmillan, 246-68

Tullock, Gordon (1991), "Rent Seeking", in John Eatwell, Murray Milgate, and Peter Newman, eds, The New Palgrave: The World of Economics, London and New York: Macmillan, 604-9

Wintrobe, Ronald (1998), The Political Economy of Dictatorship, Cambridge: Cambridge University Press 